\title{
غريب اللغة بين التقييد والإبتذال
}

أ.م. د كاظم فضيل شاهر

استاذ اللغة و النحو جامعة القادية، كلية التربية، قسم اللغة العربية

Kathem.shaher@qu.edu.iq

07808032972

$$
\text { تاريخ الاستلام: 01-06-2021 }
$$

\section{المستخلص}

غريب اللغة هو اللفظ أو العبارة الغامضة، وقد اختلف العربُ جمهوراً و علماَء في استعماله وتوظيفه في الواقع أو في المؤلفات اللغويّة والمضان المقدَّسة، اذ جرى تقييد الغريب في العصور الأولى بمستوى الفصاحة فضلاً على تضمينه دلالة الغموض و البعد و على وفق مر اتب القائلين وطبقاتهم في مستوى الفصاحة، إلّا انَّ الامر لم يجرِ على هذا في العصور اللاحقة إذ إنَّ

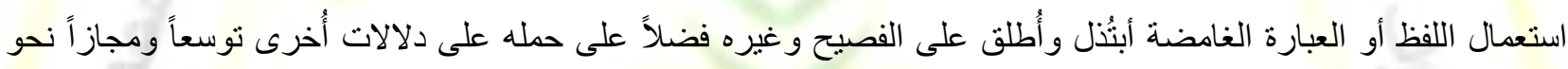
دلالات الوحشي و المولَّد و العامي والنادر و الثشاذ وتوزعه على دلالات الإبهام و الإشكال و الغموض و البعد، فمطلب الغرابة في هذه العصور شمل الغموض و البعد وزيادة، ووجِه نحو طبقات المولَّدين والعوام وفئات من سفلة الناس وطبقات الصناع وأهل المهن، فتحولت دلالته إلى الاطلاق و الابتذال.

الكلمات المفتاحية : غريب ، لغة ، تقييد ، ابتذال 


\title{
Strange language between restriction and vulgarity
}

Assistant Professor Dr. Kathem Fdhel Shaher

AL-Qadsia University / College of Education

The department of Arabic language

Receipt date: 2021-06-01

Date of acceptance: 2021-06-12

\begin{abstract}
The strange language is the wards and expressions that are vaque and far from understanding the strange expressions in the eras of protest was eloquent for those who say and transporters. But it lost that after the ages of protest during the time of the moderns so he took the meanings of the rare and the vulgar which is spoken by other than the eloquent, the ignorant, the people of the professions and the craftsmen. It became alot of use and it is not eloquent often.
\end{abstract}

Keywords : Odd, Language, Limitation, Platitude 
المقدمة:

اولاً: الغزبب، المفهوم والمصطلح

الغُربة عند الخليل: ((الاغتراب مِن الوطن، وغَربَ فلانٌ عَنَّا يَغْرُبُ غَرْباً أي تتحّى، وأَغربته: غَرَبته، أي نَحَّيتهِه... والغريب: الغامض مِن الكلام، غَرُبت الكلمة غرابة... والثَُّعرة الغريبة وجمعها غُرُب؛ لأنَّها حَدَثُ في الرأس لم يكن مِن قبلُ)(الفراهيدي

$\cdot(4 / 410$ ، 1982،

وغَرَبَ الرجل تغريباً عند ابن دريد (321هـ) اذا بَعُدَ: ((وُيقال: هل مِن مُغَرِبَّهُ خَبر؟ أي هل مِن خبر جاء مِن بُعد))، وأَعقبه

$$
\text { بقوله: ((وأَحسبُ أنَّ اشتقاق الغريب مِن هذا))( (بن دربد ، } 1932 \text { ، 1/268) }
$$

ومِمَّا أورده الازهري (370هـ) منسوباً الى الليث: ((والغريب مِن الكلام العُقّمي الغامض)) (الازهري ، 1967، 117-8/112 ) والعُقِميُّ: ((غريب الغريب، وه غامض الكلام الذي لا يعرفه الناس، وهو مثل النوادر، وقال أبو عمرو: سألت رجلاً مِن هذيل عن

$$
\text { حرفٍ غريب فقال: هذا كلام عُقِيُّ، يعني أنَّه مِن كلام الجاهلية لا يُعرف اليوم))( نفسه) }
$$

وقال الاصدعي (213هـ): ((أَغرب الرجل إغراباً اذا جاء بأمرٍ غريب... أَغرب الرجلُ في منطقه اذا لم يُبْقِ شيئًاً إلّا تكلم به،

$$
\text { وأغرب الفرس في جريه هو غاية الاكثار منه)) ( نغسه) }
$$

وتَغَرَبَ واغترب بمعنى فهو غريب عند الجوهري ((وَأغرب الرجلُ: جاءَ بشيء غريب... واغربَ الرجلُ صار غربباً... وغَرُبَ

$$
\text { عني: أي بَعُدَ))((الجوهري ، 1999، 290-1/288 ) }
$$

ووجّةَ ابن فارس (395هـ) الغَربة نحو البعد ومنه ((غروب الثمسُ، كأنّه بُعُدها عن وجه الأرض)) وقول الخليل: ((اذا أمنعت

$$
\text { الكلابٌ في طلب الصيد، قبل: غَرُبت))، فيه نظر (ابن فارس ، } 1993 \text { ، 4/421) }
$$

والذي أنكره ابن فارس نَصَّ عليه الأصمعي وهو الأقرب إلى دلالة اللفظ، إذ إنَّ الاكثار مِن الثيء والامعان في طلبه يعني التباعد في تحصيله.

ومِمَّا زاده ابن سيده (458هـ) في هذا الموضع أنَّ (أُغتربَ الرجل: نكحَ في الغرائب.... وقِذح غريب: ليس مِن الثجر التي سائر القِداح منها))، وقريب مِن ذلك - عنده ((رجل غريب: ليس مِن القوم)) ( ابن سيده ، 5/299،2000 ) وقد توسّع الزمخشري (538هـ) في دلالة هذا اللفظ وَجلَّى وجوهاً أُخَرَ استوحاها من أقوال سلفه مِن العلماء، إذ ذكر أنَّ قولهه: (تكلَّم فأغرب: اذا جاء بغرائب الكلام ونوادره، ويقولون: فلان يُغْرِبُ كلامهويغرب فيه، وغرب كلامه، وقد غَرُبت هذه الكلمة: أي 
غمضت فهي غريبة ومنه مصنف الغريب... وُيقالُ: وجه كمرآة الغرببة، لأنَّها في غير قومها، فمرآتها أبداً مَجُلُوَّة، لأنَّهَ لا ناصح لها في وجهها، ومِن المجاز استعاروا لنا الغربية، وهي رحى اليد، لأنهَّا لا تقَرُّ عند أَربابها لكونها متعاورة)(( الزمخشري ، 1979 $(683$ ،

وقد ظَلَّتَ المعجمات الحديثة تدور في فلك ما ذكره القدماء ولم تأت بجديد في دلالة اللفظ سوى توظيفها الدلالات التي قرَّها القدماء في المطالب الحديثة( المعجم الوسيط ، 1989 ، 647 ) (لاروس ،888،1988-887) يظهر مَّما تتبعناه في المعجمات أنَّ مفهوم الغريب يصدر من معنيين رئيسيين: الأول: الغامض في كلّ أنحائه ومنه الكلام القديم الذي خفي على الناس لجهلهم به، والمشكل لخفاء الدلالة أو دقة المعنى، والنادر وقليل الاستعمال، والثاني: الحداثة والطروء في اللفظ والمعنى ( شاهر ، 1988 ، 33-34)، ولا يمكن الركون إلى أصل لغويّ جامع لا تشذَّ عنه بعض فروع الدلالات التي سطرناها في هذا الباب. فابن فارس عدَّة أصلاً إلاًّ انَّه غير منقاسٍ ولكنه متجانس على حدَّ قوله، ولذلك كتبه على جهته مِن غير طلب لقياسه(ابن فارس ( $4 / 421$ ، 1993 ، ويظهر أنَّ معنى الغرابة الذي ألفناه في العصور الأولى والذي يتوجه مِن الغموض والندرة والإبهام مّمِا كان مِن معايير الفصاحة والطبع اللغوي السليم التي مَيَّزت الخواص والجهابذة حينذاك بدأ ينحل ويتشظى في الازمان اللاحقة الى دلالات أُخر على ما سنرى في قادم موارد البحث - إنْ شاء الله. إلاَّ أنَّ الباحث ومع مزيدٍ مِن التأمل يمكن أنْ يرسم معنى للغرابة لا يخرج عَن وجهي الخفاء والبعد، اللذينِ تعاضدا في تكييف دلالة مناسبة يمكن ملاحظتها في كُلَّ ما يُتَصََّّر مِن معنى الغرابة، ودلالة البعد تصدر مِن كلَّ ما تفرّع مِن معاني الغرابة، فالغموض والخفاء والإشكال وجوه تتفرَّع مِن أَصل عام يوحي بعدم الوضوح، وكذا الحداثة والطروه بُعْدُ ومفارقه لمِا عَتِقُ، وفيهما تعمية لمِا قَدُم أو شاعَ استعماله بين الناس. وليس بعيداً عَن هذا مّمِا اصطُحح عليه مِن أنَّ الغرابة ((كون الكلمة غير ظاهرة المعنى ولا مأنوسة الاستعمال، سواء كانت بالنظر إلى الأعراب الخلّص أم بالنظر إلينا وتلك الكلمة تسمى غريباً ويقابله المعتاد ويرادفه الوحشي)(التهانوي ،1996 $(1250 / 2$ 。 ونستطيع أنْ نقترحَ تعريفاً جامعاً مانعا قابلاً للمناقثة للغريب وعلى النمو الاتي: 
(اللفظ أو التركيب المشكل غير واضح المعنى - غالباً - ولا مأنوس الاستعمال بالنسبة لعامة الناس سوى فئة اختصَّت به أو مجموعة محدودة تعاورته، وهو على درجاتٍ مِن الفصاحة أو دركاتٍ غيرها، تبعاً للزمان والمكان وصفة القائلين وأجناسهم)). إنَّ هذا التعريف الذي احتملناه مِن خلال جمع شتات الدلالات التي تقرع اليها مفهوم الغريب يذهب به مذهبين: مذهب يضعلُ على جادة التقييد ببسطِهِ على مستويات لا تفارق كلام المطبوعين واقوالهم التي جُبلوا فيها على العربية الفصيحة شعرِها ونثرها فضلاً عضن المتتين الدقدَّسين القرآن الكريم والحديث الثريف. ومذهب لا يلتزم بهذه الحدود بل يتجاوزها الى مستويات أُخر حلقت به خارج فضاءات الفصاحة المعهودة وإنْ بقيت متمسَكة بمبدأ الابهام والثذوذ وانزواء الاستعمال الرصين، وفي الموردين اللاحقين ما يوضح ذلك ويُجليّيه - انْ شاء الله.

ثانياً: تقييد الغريب اللغوي:

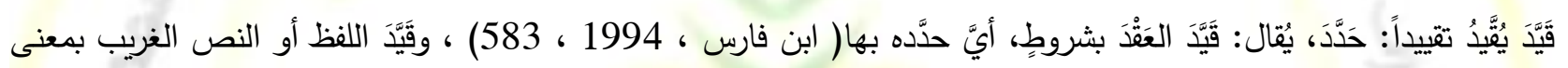
حَدَّده وضبطه بشروط لا يحيُّ عنها. والذي نريدُه في هذا الموضع أنّ أعلامنا القدماء ربطوا الغريب - غالباً - بمستوى الفصاحة ولا نقول حَقل البلاغة لتصوّر الغموض والابهام فيه وهو ممِا لا يناسب هذا الحقل، إلاًّ في مواضع مِن متونِ الموروث اللغوي كالقرآن الكريم والحديث الثريف وشيء مِن الموروث اللغوي في غيرهما؛ إذ إنَّ هذه الحقول اكتسبتٌ عنصر البلاغة التي تلكَّستْ بلونٍ مِن الغموض والإبهام الذي لا يتحقق في غيرها. إنَّ توصيفات هؤلاء الاعلام للغريب تكادُ تتفقُ في وضعه في حقل الغوض والابهام أو المشكل الذي لا يُرصدُ تركيبه أو دلالته يُّل إلا الجهابذة والخواص مِن علماء اللغة. والفصاًحة التي نعنيها في هذا الموضع متوفرة لا محالة في المتن محل الثاهد وكذا في القائلين والواصفين، ونعني بالقائلين المطبوعين حينذاك والذين جبلتهم اللغة التي نصفها بالفصيحة أو النقية التي تُعتمد في هذا الموضع ويُنْحِجّج بها؛ ونعني بالواصفين العلماء الناقلين والراصدين للغريب.

قال الزجاجي في الفرق بين النحو واللغة والاعراب والغريب: ((وأمّا الغريب فهو ما قلَّ استماعه مِن اللغِّة، ولم يُُر في افواه العامة كما دار في افواه الخاصة، كقولهم: صكمت الرجل: أي لكته، وقولهم للشمس: يوح، وقولهم: رجل ظروري للكيس.... 
وهذا كثير جداً، وهذا وما أثبه، وانْ كان غريباً عند قوم فهو معروف عند العلماء، وليس كلّ العرب يعرفون اللغة كلها، غريبها وواضحها، ومستعملها. وشاذها؛ بل هم في ذلك طبقات يتفاضلون فيها....)) ( الزجاجي ، 1973 ، 92) والقيود التي رَصَدها الزجاجي هنا واضحة؛ اذ إنَّ الغريب عنده: الذيَ قلَّ استماعه مِن اللغة ودار في افواه الخاصة وهو معروف عند العَلماء، بل هم في ذلك طبقات يتفاضلون فيه. ولا شغل للعلماء بغير الفصيح المعتِّ به، وكَّ ما في الامر هو البحث عن دلالة هذا الفصيح ومعناه. ولا شكَّ أَنَّ قيد الفصاحة لا يكفي فيما نحن بصدده من ضوابط الغريب، بل إنَّ هذا القيد لا يتجاوز التوصيف العام هنا، إذ إنَّ الغموض والابهام أو الثذوذ والندرة وغيرها صفات ملازمة. لهذا الباب، بل هي المحتكم الجوهري الذي لا غنى عنه في فرزه عن غيره. فأمَّا التوسَّعُ في هذا الباب ومجاوزة قيد الغموض والابهام فسيخرجُه مِن فضاء الغرابة وينأى به نحو الإبتذال غير المراد في الغريب اليُقيدَّ بشرطي الفصاحة والغموض فضلاً على ملازماته مِن اللطافة والرصانة واكتناز المعنى والثحن الدلالي فيما يردُ في المتن القرآني والحديثي وشيء مِن كلام العرب وتاريخ المدونة اللغوية يُعَوَي هذا الذي نذهبُ اليه ويُعضّدهُ، فَمِن ذلك أَنَّ الخليفة أبا بكر سُئل عن قوله تعالى: ((وفاكهةٍ وأبّا))، فقال: ((أَمّا الفاكهة فأعرفُها، وأمّا الابّ فاله اعلم)) (16). (الهجلسي ،

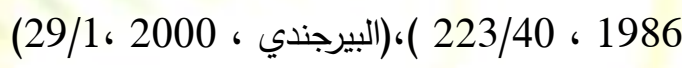
وقيل: أنَّ الخليفة عمر قرأ الآية على المنبر فقال: ((هذه الفاكهة قد عرفناها، فما الاب؟ ثم رجع الى نفسه فقال: إنَّ هذا الكلف يا عمر ()( السيوطي ، 3،4/1960،2) ورُويَ أنَّ الامام علياً بلغه ذلك فقال: ((إنَّ الابَّ هو الكلاً والمرعى وإنَّ قوله تعالى: ((وفاكهةً وأبا)) اعتداد مِن الله على خلقه فيما غذاهم به وخلقه لهم ولأنعامهم مِمَّا يحيا به أنفسهم)(المجلسي ، 1986 ، 223/40 )،(البيرجندي ، 2000 ، 29/1) وينقل لسيوطي في إتقانه في النوع الذي ينصّ على معرفة الغريب أثياء مِن هذا خاض فيها بعض صحابة رسول الله (صلى الله عليه واله وسلم) وتابعيهم ووققوا منها على ساكن، اذ لم يعرفوا معناها وهم العرب العرباء وأصحاب اللغة الفصحى وَمن نزل القرآن عليهم، ويرى السيوطي أنّ ((على الخائض في ذلك التثبت والرجوع الى اهل الفن، وعدم الخوض بالظن))( السيوطي ، 
وسؤلات نافع بن الأزرق إلى ابن عباس التي نقل الكثير منها السيوطي في كتابه المذكور، وَذََّّل بها محمد فؤاد عبد الباقي كتابه (معجم غريب القرآن)، خير شاهد على ما نقول.

ويظهر أنَّ هذه السؤالات التي ضمتها بطون بعض الكتب ومنها الاتقان وسلخها الأستاذ محمد فؤاد وضمها لمعجمه أثارت فضول الدكتور إبراهيم السامرائي لمكانها التاريخي في علم التفسير، فعد الى تحقيقها بعد حصوله على مصورة المخطوط المحفوظ في دار الكتب المصرية ومثلها في خزانة المجمع العلمي العراقي ضمن مجموع مشتمل على عِدَّة مظانَّ. ولا يُنْينا أَمر التحقيق هذا سوى أَهمية هذه الوثيقة في تتبيت حقيقة الغريب الذي سميناه بالمقَّيد والذي نال أَعلى مراتب الفصاحة لوروده في الكتاب المجيد.

وسؤالات نافع الى ابن عباس حوار بين الرجلين تضمَّن آيات كريماتٍ اشكلتْ على الناس وعمِيت عليهم دلالاتها وأُبهت أشياء منها على فضلاء الصحابة كما نقلنا فهي مِن الغريب بلا شك فالأمر في هذه السؤالات يتوجه مِن القرآن، إذ إنَّ نافعاً وصاحبًَ نجدة بن عريم يحاوران ابن عباس في أشياء من كتاب الله عز وجل ويطلبان تقسيرها والإتيان بمصاديقها من كلام العرب، إذ إنَّ القرآن أُنزل بلسانٍ عربي مبينٍ. والرواية المسندة في هذه السؤالات تُشير الى أنَّ ابن عباس كان جالساً بفناء الكعبة وقد أسدل رجله في حوض زمزم، والناس قد اكتنفوه مِن كلَّ ناحية يسألونه من تقسير القرآن. وظنّ الرجلان أنَّ ابن عباس كان يجترئ على تفسير القرآن والفتيا بما لا علم له به، وصَرَّحا بذلك فقال ابن عباس: ((لا والله ما هذا مني تَخرَّصاً لكنه علم علمنيه الله، ولكني سأدلك على من هو أجرأ مني يا ابن أم الأزرق، قال: دلني عليه، فقال: رجل تكلُ بما لا علم له به، أو رجل كتم الناس علماً علَّمه الله عز وجل، فذاك أجرأ مني يا ابن أم الأزرق))( السامرائي، 1968،

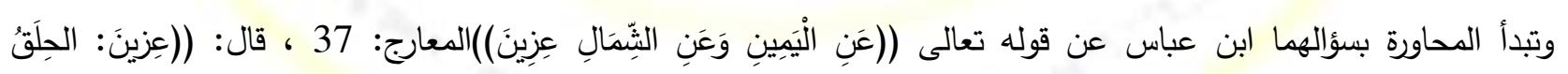
الرفاق، قالا: وهل تعرف العرب ذلك؟، قال: نعم أما سمعت عبيد بن الابرص وهو يقول: فجاءُوا يهرعون اليه حتّىى يكونوا حولَ منبره عِزينا))( السامرائي، 1968،8) واسئلة أَخرى منها: ((أَخبرني عن قوله ((شِرْعَةً وَنْهَهاجًا))(المائدة:48) ، قال: الثِرعة: الدين، والمنهاج: الطريق، قال: وهل تعرف العربُ ذلك؟، قال: نعم، اما سمعت أَبا سفيان ابن الحارث بن عبد المطلب وهو يقول: 


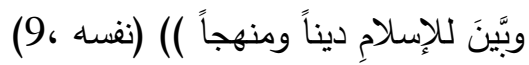

لقد نطق المأمونُ بالصَّدقِ والهدى

ويجري الحال هكذا الى آخر الحوار بسؤال ابن عباس عن قوله تعالى: ((إنَّ المَّاعَةَ أَتِيَّة أَكَادُ أُخْفِيهَا)(طه ،15) ، قال ابن عباس: ((مِن كُلَّ أَحد، وفيها كلمة عربَّيَة يا ابن الأزرق لعلك لا تحتملها، قال: بلى يا ابن عباس فاخبرني بها فقال: نعم، أُخفيها عن علمي، قال: وهل تعرف العرب ذلك؟ قال: نعم أَما سمعت الثاعر وهو يقول:- فإن تدفنوا الداء لا نُخفِِِِ

$$
\text { وإنْ تبعثوا الحرب لا نَعُعُ)() (نفسه ،63) }
$$

ويمكن للباحث المتأمل أَنْ يصلَ الى قناعةٍ راسخة بطروء هذه الغرابة على المجتمع القرشي حيذالك ودليلنا على ما نقول جو الرواية الذي يُشير الى اجتماع الناس حولَ ابن عباس بفناء الكعبة وسؤالهم إِياه عن أَثياء في القرآن لم يقعوا على تقسير لها، وتكامل الامر بالتحاقِ نافع وصاحبه بالركب وطلبهما إجابات مِنّ ابن عباس عن أشياء وردت في القرآن ولم تتّضحْ دلالاتها بعد على ذلك المجتمع الذي ورث مستوى لا بأس به من سليقة العربية المشتركة النموذجية وجرى على جبلتها، ولا شك في أنَّ هذا الجمهور الذي اكتنف ابن عباس لم يكن قرشّيّاً خالصاً مادام الامر يتعلق بمكانٍ يمثل موضع تلاقٍ بين العرب لزيارة أو تجارٍ كما عُهََِ ذلك في الكعبة الثريفة. وما كان هؤلاء يسألون عن أشياء موجودة في لهجاتهم أو شاعت في العربية المشتركة، فلا شك أُّنَّ ما سألوا عنه كان غريباً عن هذه اللهجة أو تلك ولم يشعْ في أوساط المجتمعات العربية، والمَّرُ في توظيفه قرآنياً رصانته وسلاسته أو جزالته ولطافته مّمِا لم يتوفر في الفاظ أو تراكيب عربية شائعة، واستعمال المعَربات والدخيل لم يكن بعيداً عن هذا الباب، وما كان القرآن ليستعمل الفاظاً أو عبارات عُدَت في حقل الغريب مع وجود مرادفاتها العربية الثائعة، التي يمكن أنَّ تملأ فضاءها الذي تثغله بقوة سبكها

$$
\text { وشحنها الدلالي الذي لا يتوفر عليه سواها.( الجواري ، 1974، 15-26) }
$$

ونحن هنا لا نوافق ما أَقَّهَ العلامة عبد القاهر الجرجاني في حَصْره الاعجاز في منحى نحَّوي تركيبي فقط (عبد القاهر ،2004 ، 55 -56 ) ، إذ إنَّ القضية لا تقف عند الدد الذي تبناه، فغرائب القرآن تتجاوز ذلك - بلا شك - الى رصانة الالفاظ وسبك

$$
\text { حروفها الذي لا يُّانيه في صناعته ورصفه سواه. }
$$

فمرتكزات الغرابة: الالفاظ بدءاً ثم تألقها وما يلحق ذلك من خصائص تلزم المعنى الدلالي المستفاد مِن وجوه الاستعارة وغيرها مِن ألوان المجاز مما نَسَّ عليه عبد القاهر نفسه. ( نفسه ، 387) 
فغوض اللفظة الفصيحة أو العبارة البليغة هو المرتكز في هذا الموضع وهو موضع اتفاق بين العلماء والمحققين اللغويين والبلاغيين والنقاد واهل المعاني .( السيوطي ،2،1960) وقد أصاب الزركثي كبد الحقيقة والمسألة وادلى بكلامٍ مهم ومفيد في هذا الموضح، فهو بعد أنْ قسَّم علوم القرآن الى سبعةٍ وأربعين نوعاً، جّعل النوع الثامن عشر: لمعرفة الغريب وسمَّاه (معرفة المدلول)، اذ ذكر جمهوراً مَِّن الف فيه وذكر أنَّ احسنها كتاب ((المفردات)) للراغب الاصفهاني، الذي تَصيَّد المعاني من السياق، لانَّ مدلولات الالفاظ خاصَّة، والكثف عنها بحاجة الى معرفة علم اللغة اسماً وفعلاً وحرفاً، والحروف - لقلتها - تتاولها النحاة ووققوا على معانيها، فأمَّا الأسماء والافعال فتؤخذ مِن كتب اللغة على حَّد وصف الزركثي في برهانه. (الزركثي ، 1990 / 291/1-292) ومعرفة فن الغريب ضرورة للمفسر ولا يحلَّ الاقدام على كتاب الله بغير ذلك ويلزم أنْ يكونَ عالماً بلغات العرب وحقائق اللغة وموضوعاتها.(نفسه ، 294/1 ) ولابي سليمان الخطابي (388هـ) كلام في غاية الأهمية فَسَّر فيه الغرابة ورصد وجوهها المحتملة بما يوافق هذا الذي ذكرناه في هذا الموضع، قال: (الغريب مِن الكلام انما هو الغامض البعيد من الفهم، كالغريب مِن الناس، إنما هو البعيد عن الوطن المنقطع عن الاهل، ومنه قولك للرجل اذا نحيته أو اقصيته: اغرب عني: أي ابعد... فيقال: غرب الرجلُ يَغْرُب غَرْباً اذا تتحّى أو ذهب، وغرُبَ غُرَبَة اذا انقطع عن اهله وغَرُبت الكلمة غرابَة وغربت الثمس غروباً، ثم ان الغريب يقال به على وجهين: أَحدهما: أنُ يُراد به بعيد المعنى غامضُةٌ، لا يتتاوله الفهم الاّ عَن بعد ومعاناة فكر. والوجه الآخر : أن يراد به كلام مَن بَعُدت به الدار، ونأى به المحِلَّ مِن شواذ قبائل العرب، فإذا وقعت الينا الكلمة مِن لغاتهم استغربناها، وانَّما هي مِن كلام القوم وبيانهم، وعلى هذا ما جاء عن بعضهم وقال له قائل: أسألك عن حرف مِن الغريب، فقال: هو كلام القوم، إنمّا الغريب انت وامثالك مِن الدخلاء فيه)).(الخطابي ، 1982 ، 70/1) والخطابيّ كغيره مِن علماء الغريب يوجزُ لنا خلاصة تجربته في معرفة الغريب بعد الخوض في غمارة ممّا سبره مِن كلام العرب، وممّا وقف عليه مِن كلام الرسول الأعظم (صلى الله عليه وسلم) فهو بعد أنَّ قرأ حديث الرسول الأعظم (صلى الله عليه واله وسلم) قراءة متأنية وواعية وجد أنّ الذي ذُكر من جوامع كلامه (صلى الله عليه واله وسلم) وفُصَّل مِن ضروب بيانه يكفي سبباً لكثرة ما يوجد من الغريب في حديثه (صلى الله عليه واله وسلم) وقد ذكر الخطابي ضروباً مّمِا أُثر مِن حسن بيان النبي (صلى الله عليه واله وسلم) وما أُمِدَّ مِن جوامع الكلم التي جُعِلَتْ ردءاً لنبوته وعَلماً رسالته. 
فمنها في القضايا والاحكام كقوله (صلى الله عليه واله وسلم): ((المنيحةُ مردودة والعارية مؤداة، والدين مَقضِيَّ والزعيم غارم))،

فالحديث على خفة لفظه عندِ الخطابي يتضمن عامة احكام الأنفس والأموال. (نفسه ) ، (الهروي ، 1769,2003/ 1) ومَّمِا يُنسبُ إلى فصاحته (صلى الله عليه واله وسلم) وحسن بيانه انه ((قد تكلم بألفاظٍ اقتضبها لم تُسمع من العرب قبله، ولم توجد في متقَّدم كلامها، كقوله : (مات حَتفَ أنفه) وقوله: (جِمي الوطيس)... وقد يدخلُ في هذا النوع احداثه الأسماء الثرعية....))، التي خصّص لها موضعاً آخر · (الخطابي ، 66,1982-65) ،(ابن الجوزي 11475,2004) ومن فصاحته وسعة بيانه أنَّهَ قَد وُجد في كلامه الغريب الوحشي الذي يعيا به قومه وصحبه وهم عَربّ صُرحاء، لسانهم لسانه، ودارهم داره ومِن ذلك:

(أنَّ رجلاً قال: يا رسول الله، مَنْ أَهل النار؟ قال: كُلَّ قَعَبريّ، قال: يا رسول الله، وما القعبري؟ قال: الثديد على الاهل، الثديد على العشيرة، الثديد على الصاحب)) ( الخطابي ، 1982 ، 66/1) ، ( ابن الاثير 2005، آخر هو قوله (صلى الله عليه واله وسلم): (الا أُنبئكم بأهل النار؟ قالوا: بلى يا رسول الله، قال: كلّ جطٌ جَغْظِ، قلت: ما الجطٌُ قال: الضخم، قلت: ما الجعظ؟ قال: العظيم في نفسه)). ( الخطابي،1982، 67/1) ، ( ابن الاثير، 276,2000-11274) وهكذا يجري الخطابي في بيان غريب حديث النبي (صلى الله عليه واله وسلم) بتفصيل لم نجذه عند غيره من علماء غريب الحديث النبوي والذي نبغيه ونطلبه مِن استرسالنا مع هذا العلامة أَننا وضعنا المتلقي في صورة ما قلناه مِن أنَّ الغريب يمثل وجهاً مِن وجود الفصاحة اللفظية والبلاغية التعبيرية وهذا الغريب يندرج - بلا شك - في حدود الغريب المُقَّيد، والقيد - كما ذكرنا - في القائل والقول، فالقائل رسول الله (صلى الله عليه واله وسلم) الذي يمثل جوهر الفصاحة ولب البلاغة، وهو الرسول النبي الذي نطق بلسان عربيًّ مُبين، والابانة هنا - بلا ريب - نسبية حالها حال النص القرآني الذي نوهنا به في مقَّم المبحث ونختم به - ان شاء الله هذا البحث. فقولنا بالإبانة هنا أنهَّ كاَن مُبلَّفاً ومُعَلَّماً والاسماع اليه مصغية والقلوب واعية، وقد تختلف عباراته (ويتَكرَّ فيها بيانه؛ ليكون أَوقعُ للسامعين، وأَقرب الَى فَهْم مَنْ كان منهم أقلَّ فقهاً وأقربَ بالإسلام عهداً واولو الحفظ والاتقان مِن فقهاء الصحابة يرعونها كلها سمعاً ويستوفونها حفظاً ويؤدونها على اختلاف جهاتها... وقد يتكلم (صلى الله عليه واله وسلم) في بعض النوازل وبحضرته اخلاطُ مِن الناس، قبائهم شتى ولغاتهم مختلفة، ومراتبهم في الحفظ والاتقان غير متساوية، وليس كُلهم يَتَيسَر لضبط اللفظ 
وحَصْره أو يتعمد لحفظه ووعيه وانما يستدرك المراد بالفحوى، ويتعلق منِه بالمعنى، ثم يؤديه بلغته وَيعَبَّر عنه بلسان قبيلته، فيجتمع في الحديث الواحد اذا انشعبت طُرقه عدَّة الفاظٍ مختلفة موجبها شيء واحد...)).(الخطابي ،1982 ، 68/1-69) وهذا الذي ذُكر مدعاة لتكاثر الغريب، اذ إنَّ تكرار لبيان النبوي لغرض التأثير واختلاف الاحكام والتلقي عنه (صلى الله عليه واله وسلم) واشكالية الحفظ والاتقان، فضلاً عن اختلاف لهجات المتلقين، الذين يرصدون كلامه وافعاله وتقريراته فينقاونها الى اقوامهم ومنهم الحافظ المتقن ومنهم دون ذلك فيرتكبون النقل بالمعنى الذي هو دون كلام النبي (صلى الله عليه واله وسلم) بلا ريب، فتحصل النسبية في الفصاحة والبيان وهم في ذلك طبقات في تصيدأقوال النبي (صلى الله عليه واله وسلم)، أعلاها الذي تملَّك ناصيته الفصاحة والبيان فينقل عن النبي (صلى الله عليه واله وسلم) ما سمعه بلا تغيير اذا كانَ حافظاً ومتقناً ثم ما دون ذلك والنبي (صلى الله عليه واله وسلم) يثكل قمة الهرم وناصيته في ذلك وقد حثَّ على نقل حَديثه كما هو بقوله (صلى الله عليه واله وسلم): ((نََّّر الله عبداً سمع مقالتي فحفضها ووعاها وأدَّاها...))، اذ رتَّب الوعي على الحفظ مشترطاً تلقف الالفاظ وجمعها في الصدر ومراقبتها بالتذكر وتخولها بالاستفهام والرعاية لتؤدّى كما هي فيخرج الناقل مِن العهةة فيها.(نفسه ، 67/1) ،(ابن الجوزي،414/2,2004) وفي هذا الكلام ما فيه مِن الحث على تَقََّصِ الفصاَحة والبيان، وهو يوحي بوجود آخرين لا يقدرون على ذلك فينقلون بالمعنى وهؤلاء على درجات مِن البيان كذلك، وهذه هي النسبية التي كرّرنا لكلام فيها على درجات الفصاحة في الغريب. يتبع ذلك بل يوازيه ما يصدر في هذا الباب مِن اختلاف لغات الناقلين والروايات عن النبي (صلى الله عليه واله وسلم) أو اصاحبه وهو محتكم جوهري لا يمكن تجاوزه؛ اذ بَسط سلطته على المتتين الثريفين القرآني والحديثي ونبه عليه العلماء المحققون وقد وجدنا ذلك واضحاً في مداخلات الخطابي مِمَّن ولج الباب ومخض القول فيه. (شاهر ،2008 ، 65-75) والذي يتَتَّعُ ما كتبه العماء في المتتين المذكورين يجد ذلك واضحاً لا لبس فيه، وقد مَّر بنا ما سطره علماء غريب الحديث ولا سيما الخطابي في هذا الموضع وقد ذُكر في مَحَالّة بما لا مزيد عليه هنا.( نفسه ، 65-87) والذين كتبوا فيه متوجهين مِن المتن القرآني كثيرون وقد ركَّزوا على توضيح لكلمة الغريبة أو المشكلة مِن القرآن فشرحوها وفسَّروها لتقريب معناها ومدلولها مع اهتمامٍ غير قليل بالقراءات وعناية جَلّية بالنحو والصرف والدلالة وبالثواهد مِن الثعر والحديث وآراء أَئمة اللغة واقوال العرب.( ابن التركماني ، 2002 ، 35-44) وقد خصَوا مظانهم بأسماء تدل على ذلك مِن مثل معاني القرآن أو تأويله أو غريب القرآن أو مجازه ومشكله.( نفسه ) 
والمشكل عند هؤلاء - كما عند علماء غريب الحديث - يتوجه من مستويات التصريف والتركيب والدلالة وقد خاض فيه الباحثون بما لا مزيد في هذا المورد متخذين مِن المتتين المقَّدين ساحةً لتشخيص مكامن الإشكالات الصوتية والصرفية والنحوية والدلالية والاسلوبية التي تتحو نحو الغرابة في تثكيل البنية اللفظية والتركيبية في كلمات المتنين ونصوصهما.( عرار 2003 20319-

والاشكال المنتمي للغرابة والناشئ مِن اللهجات واضح في المتنين وقد ذكرنا شيئاً منه في متن الحديث وهو في المتن القرآني أوضح وأجلى، وشأنهُ جليل عظيم وقد عُني به العلماء وأهل النظر في اللغة منذ القرن الأول للهجرة فألف فيه الفراء والاصدعي والهيثم بن عدي ومحمد يحيى القطيعي، واذا دقَّقَت في أسماء هؤلاء ظهر شأنهم، واكثرهم مِن اعلام اللغويين وعنايتهم بلغات القرآن وتآليفهم دليل على عظم شأن هذا الموضوع. ومَّما ألَّقوا في هذا الباب ((كتاب اللغات في القرآن، رواية ابن حسنون المقرئ بأسناده الى ابن عباس))، وقد أطلقت على تحقيقين لئً الأول للدكتور صلاح المنجد والأخر للدكتور توفيق محمد شاهين. وقد أُفرد الكتاب لما في القرآن مِن لغات القبائل والأمم، وقد رُتَّب على السور وَسُرد ما في كلّ سورة مِن الفاظ القبائل العربية والفاظ الأمم الأخرى كالفرس والروم والانباط والسريان والعبرانيين، فهو قد بين مصادر القرآن اللهجية واللغوية وألقى الضوء على لغات القبائل قبيل الإسلام وَحدَّد نسبة ما أَخذ القرآن مِن الفاظ كل قبيلة مِن القبائل، ثم مِن كُلَّ أَََّة، اذ فيه الفاظ أَعجمَّية وليست

$$
\text { عربية على الأرجح. ( ابن حسنون ، 5-5 } 1972 \text { (6) }
$$

والكتاب يمتاز بإضافة قبائل غفلها السيوطي في الاتقان وقد حَّدد الدكتور صلاح المنجّد نسبة ما أخذته كلّ قبيلة اذ كان لقريش النصيب الاوفر، لأثّا كانت أعظم القبائل سلطاناً وسياسة وتجارة وافصحها لغة، فسلطانها وتجارتها ساعدا على نشر لغتها بين القبائل التي كانت متعددة اللهجات متباينة اللغات، والتأثير المتبادل طبيعي في هذا الموضع. والقرآن قد أَخذ من معظم القبائل، ولا يمكن الجزم بالأخذ مِن كل القبائل العربَّية، ونجد أنَّ القرآن قد أَخذ مِن الفاظ معظم القبائل القحطانية مِن حيث الأصل، وإن قلَّتُ نسبة أَخذها عن القبائل العدنانية الثمالية. يبدأ الحديث فيها بسورة البقرة الآية الثالثة عشرة ((أنَؤمِنُ كما آَنَ السفهاء))، ذكر أنَّ السفيه: الجاهل بلغة كنانة. ثم قوله ((رَغداً)) مِن الآية الخامسة والثلاثين، قال: يعني الخصب بلغة طيء. 
وهو يسترسل فيذكر مواضع من لهجات القبائل كقوله ((تلك أمانَّهم)) مِن الآية الحادية عشرة بعد المئة مِن البقرة، والاماني: لأباطيل بلغة قريش، وجَنَاًمِن الآية الثانية والثمانين بعد المئة مِن سورة البقرة تعني (تعداً) بلغة قريش كذلك. و((دأبٍ آل فرعون)) مِن الآية الحادية عشرة مِن آل عمران تعني أَشباهم بلغة جُرهم، و((أخذذة رابية)) مِن الآية العاشرة مِن الحاقة تعني: الثديدة بلغة حِيَر، و((الخرطوم)) مِن الآية السادسة عشرة مِن سورة القلم يعني الانف بلغة مدحج. ومَّمِا أَخذ مِن لغات الأمم الأخرى ((مقاليد)) مِن الآية الثالثة والستين مِن الزمر، وتعني المفاتيح، موافقة للغات الفرس والانباط والحبشة، و((اليَّة) مِن الآية الأربعين من سورة الذاريات هو البحر، بلغةٍ توافق النبط، و((كِفْل منها)) مِن الآية الرابعة والثمانين من سورة النساء تعني النصيب بلغةٍ توافق النبطية (نغسه). وهكذا يجري الامر في الكتاب بذكر اللهجات واللغات التي تضمنتها الآيات الكريمات، وكُلّ ما ذُكر في هذا الموضع هو مِن الغريب والمشكل كما نَصَّ عليه العلماء المحققون في هذا الموضع( نفسه ، 17-18-36-37) ، ( ابن قتيبة ، 2007 ، 46 $\cdot(311-305-73-$

ويمكن القول إنَّ كلَّ ما ورد في هذا الموضع هو مِن الغريب الذي اعتلى قََّّة هرم الفصاحَة وقُيَّة بأعلى درجاتها؛ اذ انَّ المتصور فيه وخصوصاً في مسألة اللهجات أنّ المتن الكريم كان يختار مِن هذه اللهجات الأفصح والأحسن والادق والالطف. والثابت أنّ الناطق على قياس لغةٍ مِن لغات العرب مصيب غير مُخطي، على ما يرى ابن جني في الباب الذي سلكه في خصائصه بعنوان ((باب اختلاف اللغات وكلَّها حجة)( ابن جني ، 1999 ، 12/2-14) ، ولا يخفى أنَّ أعلى اللغات هي لغة القرآن والحديث الثريف. وهذا يجري على قول العرب في عصور الاحتجاج، اذ ثبت توفر لفصاحة في تلك العصور، فثبت القبول للثيء يُسمعَ مِن العربي الفصيح، ولربما لم يُسمع مِن غيره، اذ انَّ غير المسموع مِن غيره أما أنْ ((يكون شيئًاً أخذه عَمَّن ينطق بلغة قديمة لم يثاركْ في سماع ذلك منِه... وأما أن يكون شيئًاً ارتجله... فإنّ الاعرابي اذا قويت فصاحته، وسمت طبيعته تَصرَّف وارتجل ما لم يسبقه احد قبله، فقد حُكِي عَن رؤبة وأبيه أنهمّا كان يرتجانان ألفاظاً لم يسمعاها ولا سُبقا اليها، وعلى نحو مِن هذا قال أبو عثمان: ما قيس على كلام العرب فهو مِن كلام العَرب)).(نفسه ، 26/2-27) 
ويلحق بذلك ما أُعرب مِن اجناس الاعجميّة التي أَجرتها العرب مجرى أَصول كلامها، وهي مِن الغريب ووجهُ مِن وجوهه - بلا ريب وهو موضع شريف كما يراه ابن جني ((وأكثر الناس يَضُعف عن احتماله؛ لُُموضه ولطفه، والمنفعة به عامَّة، والتساند اليهُ مُجّدِ، وقد نص أبو عثمان عليه فقال: ما قيس على كلام العرب فهو مِن كلام العرب)) ( نفسه ، 385/1) . فهذا مِن الغريب القياسي الفصيح واللطيف مَّمِا جرى في المتن الكريم وقد قُيَّد هنا بالغموض لمفارقته كلام العرب في أصوله، فاحْتيح في بيانه إلى شرح وتفسير مِن لان العلماء والاعلام؛ ولا يبعد أنْ يكون هذا مَّمِا هُجَِ مِن اللغة الجزرية القديمة فأحياه القرآن وقد تكون هذه اللغات التي أُشير بالنقل منها الى العربية واسطة لنقل هذه الكلمات مِن السامية الى العربية الحديثة التي نزل بها القرآن(السالم ، 2002 ، 2-92-32-52-59).

وعلى ذلك قد يكون استعمال القرآن لها وهو الذي نزل بلسان عربيَّ مبين استعمالاً على الأصل لا على الاقتراض، فيكون منشأ الغرابة فيها الغموض الذي طرأ عليها بسبب الهجر، وهي الفاظ عربية محكومة بفصاحتها ولطافتها وسبكها وشحنها الدلالي بما لا مزيد عليها في هذا الموضع.

ومهما يكن مِن أمر فانّ استعمال القرآن لها يجعلها تحتل قصب السبق وقمة الهرم في مستوى الفصاحة، ومِن فصاحة الرسول (صلى الله عليه واله وسلم) وحُسن بيانه ((أنَّهَ تكلَّم بألفاظٍ اقتضبها لم تسفْع مِن العرب قبله، ولم تؤخذ في متقدم كلامها))() (65/1) ، الخطابي ، 1982 ( 192

ففصاحة الرسول (صلى الله عليه واله وسلم) وبعض العرب بالتبع - مَّمِا أشرنا اليه في هذا الموضع - التي جعلتهم يقتضبون ألفاظاً لم تُسمع من قبل ويرتجلونها يرجح السبق القرآني في هذا الموضع؛ اذ لا يبعد أنْ يكون منشأ هذه الالفاظ أو بعضها أصالة - كما تقدم - أو ارتجالاً، وليس هذا ببعيد عن المتون المقدسة التي تصدر عن الخالق العظيم الذي خلق اللغات وَعَلّمها.

ثالثا: إبتذال الغريب واطلاقه

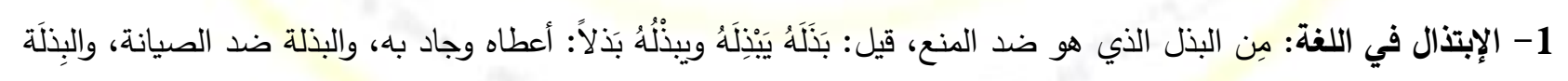

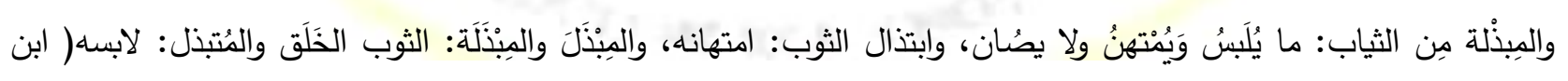
منظور ، 2010، 50) ، وفي حديث الاستسقاء: ((فخرجَ مُتَبََّّاُ مُتخضَّعاً))، ذكر اللغويون وأصحاب الغريب أنْ التَتَذّل: هو ترك التَزَيَّ والتَّهيء بالهيئة الحسنة الجميلة على جهة التواضع، ومنه - أيضا - حديث سلمان أنه ((رأى ام الََّرداء مُتَّبِّلة))، وفي رواية: ((مُُبتَّنَل))، والمراد: ترك التصاون واللفظان بمعنى واحد( ابن الاثير ، 2005، 111/1) .قيل: ((اذا رأيت كاتباً 
يبتذلْ الادب ابتذالاً فاعلم أنَّهَ ليس أديباً))، فالكلام المبتذل والأسلوب المبتذل: الذي فَقَدَ طرافتهِهِ وقيمته بسبب كثرة الاستعمال،

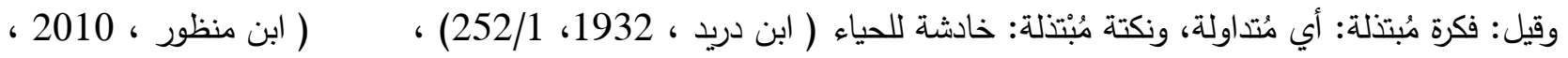
(50) ( لاورس ، 141/1988،1). ويمكن أن نخلص مَّمِا قيل أنَّ الابتذال هو ترك التصاون أو التزيّن والتهيء بالهيئة الحسنة، ويتفرع منه: امتهان الثيء وكثرة استعماله الى الحّد الذي يُعْفِدُه طرافته وقيمتهُ، وقد يخرجُ معنى اللفظ الى دلالات خادشة للحياء ( شاهر ، 2012، 3-11). 2- الابتذال في الاصطلاح: يذكر اللغويون القدماء الالفاظ المبتلة في حَقل الالفاظ المولَّدة أو التي فقدت فصاحتها لسبب مال السيوطي ، 1998، 146/1-168) • فأمّا المحثثون فنظروا اليها في حدود ما طرأ عليها مِن تطور ، وما خرج منها مِن معانٍ وظفوه في خدمة المناهج التي عُنيت بهذا التطور ، وما يجري في الاستعمال. وقد يَنْبُ اللغويون الابتذال الى العوام واللهجات الخاَّصة بهم والمتوجهة مِن المهن والصنائع أو التي تشيع عند الجهلة وسفلة القوم مَّمِا يؤول بهذه الالفاظ نحو انحطاط دلالاتها أو قبحها (شاهر ، 2008 ، 12) . وقد رافقت هذه اللهجات الفصيح في عصور العربية وقد تقترب من اللهجات المذمومة التي عرضتها كتب اللغة، ومِن شروط الفصاحة عنِد اللغويين الا تكون الكلمة مبُتنلة، والابتذال في هذا الموضع ينشأ من التغيير الى غير أصل الوضع في البنية أو الدلالة، وربما ينشأ مِن سخافة اللفظ في اصل وضعه، وقد اقترحت تعريفاً للابتذال على النحو الاتي: ((هو اللفظ الذي فقد شرطاً مِن شروط الفصاحة، لتغيير العاّمة له الى غير أَصل وضعه، أو كثرة دورانه على السنتهج، أو السخافة في أصل وضعه أو قبحه، مّمِا يؤولَ الى زواله أو اندثاره الا على نطاقٍ محدود بين العاَّمة أو الوسط الخاص به، فيحل محله لفظ اخرأقل وضوحاً في دلالته وأكثر غموضاً أو تعمية للدلالة على المطلوب)((شاهر ، 2012، 4 ) .

هذا هو مفهوم الابتذال ويعنينا منه بدءاً دلالته على كثرة الاستعمال، اذ إنّا سنجد أنَّ مِن أسباب ابتذال الغريب كثرة استعماله ودورانه على الالسن واطلاقه بلا قيودٍ أو شروطٍ تحدَّد دلالته.

وقد قلنا في بحث الغريب المُعَيَّد أنَّ الواقع اللغوي في عصور الاحتجاج جَعَلَهُ مُلْتزماً في اللفظ الفصيح المُميَّز ، الذي يصدر عَن الخواص والجهابذة وقد توفر في المتتين المقدَّسين القرآني والحديثي، وكان يُحتاج دائماً الى خواص العلماء لمعرفته والتقتيش عَن دلالته؛ اذ إنَّ هذه الدلالة غامضة ومبهمة وربّما مشكلة تحتاج الى بيان وقد يكون مصدر الغرابة لطافة اللفظة ودقتها وشحنها الدلالي الذي يحتاج الى مزيد تأمل للوقوف على دقائقها، وخير شاهدٍ على ما نقول كتب غرائب القرآن والحديث، وهم قد يصفون 
بعض الكلام هنا بالغريب الوحشي، لتوعَره وصعوبته التي يَعْيا بمعرفة دلالته الكثيرون سوى المتخَصَصين مَمَّنْ مخض لغة العرب ووقع على وقائعها (الخطابي ، 1982 ، 66/1) .وللتحديد الزماني والمكاني وجنس القائلين بها والتباين المعرفي بين المتلقين اليد الطولي في تحديد نوع الغريب الذي فرض سطوته على غيره مِن اجناس الكلام في عصور الاحتجاج، الاًّ أنَّ المتأمَّل في العصور التي تلتها يجد ابتذالاً واسعاً واطلاقاً شائعاً غير مُقيَّد بلفظ الغريب. ودليلنا على ذلك المظان التي أُلْت في هذا الباب، وهي أكثر مِن تُحْصَى في هذه الدراسة، اذ إنّ الاطلاع على بُطون هذه الكتب ومضامينها يكثف أنّ المسألة فيها لا تتجاوز الوقوف على معاني الالفاظ وتفسيرها من دون أن يقع على غموض أو إبهام في أكثر ما يرد فيها مِن الفاظ أو عبارات. فكتب الفاظ الغريب لا تحتوي مِن هذا الذي قلناه الا أشياء يمكن تصوّر الغرابة فيها، وكذا كتب العبارات والتراكيب؛ نقصد ما يُسمّى بكتب إعراب غريب القرآن أو مشكلة التي ليس فيها غرابة على وفق المعايير التي ذكرتها في هذا المورد. والذي نريد بيانه في هذا المورد أنَّ الكتب التي وسُمتْ بالغرابة احتوت شيئًا مِن الغريب الذي طلبناه في المورد السابق وأسميناه بالغريب المُقَّيد بشرط الفصاحة والغموض الاًّ انَّها استغرقت مادتها بألفاظ لا تمت الى الغرابة والابهام بصلة؛ وحدث هذا في وقت مُبَكر ، اذ إنَّ كتب غريب القرآن هي كتب معان عامَّة وكتب تفسير لمفردات أو عبارات قرآنية في مجملها، ولا يُشكلُ الغريب فيها الا مساحة محددة. وقد جرى هذا في بواكير المؤلفات التي فسّرت مفردات القرآن ومنها ((غريب القرآن)) المنسوب الى الثهيد زيد بن علي بن الحسين، فالمتتبع للكتاب يقع على جمهور من الالفاظ التي تشكل النسبة الأكبر منه وهي لا تَمُتَّ للغربب بصلة فلا بنياتها مشكلة ولا معناها غامض؛ فاذا توفر فيها عنصر الفصاحة فلم يتوفر فيها عنصر الغموض الذي يخصّص الكلمة الغريبة الفصيحة مِن غيرها فأين الغموض في مفردات مِن مثل: إهدنا والمستقيم مِن سورة الفاتحة؟: وأين الغموض في مفردات من مثل: المفلحون والمتقون والغشاوة والأليم والأستهزاء والطغيان والسجود والتواب والرحيم والكبيرة والقوة والمنخنقة والطيب وحزب الله، وألقينا مِن سورة البقرة؟! وأين الغموض في مفردات من مثل: يستغشون وغيض الماء، واعتراك، ونككِرهم، فأسرِ بأهلي؟ من سورة هود؟! والحافظ والفصل والهزل مِن سورة الطارقة؟! أو الاقتحام والتواصي، والمؤصدة من سورة البلد؟! وقوله لم يلد ولم يولد مِن سورة الإخلاص، وغيرها 
إنَّ هذه الالفاظ في غاية الوضوح والبيان وقد توافرت على الفصاحة إلا أنَّ الغموض قيد الغرابة، والفصاحة والغموض قيدان اللفظ الغريب، ومثل غريب الثهيد زيد كثيرُ من الكتب التي ألفت في هذا الباب(الثهيد ،زيد ، 1967، 59-96) . فالذي تصلح له هذه الكتب أنْ تكون كتب تفسير ومعنى، فليس مِن المعقول ان يوضع هذا مع ما وضع مِن وقفات لابن عباس فسَّر فيها الغريب الذي ضمَّة المتن القرآني واعيا كثيراً ممّن سمعه، وكذا ما نقل عن ابن عباس في بيان لغات القرآن التي شكلت مساحة لا بأس بها من هذا الغريب، وهذا الغريب الذي وَصَفه ابن عباس هو الذي سلكه الخطابي على وجهين: أحدهما بعيد المعنى، الغامض الذي لا يتتاوله الفهم الا عن بُعد ومعاناة فكر، وهذا يثكل عموم الغريب في القرآن والحديث، والوجه الاخر كلام من بُعدت به الدار مِن شواذ قبائل العرب، فاذا وقعت الينا الكلمة مِن لهجاتهم استغربناها وانما هي من كلام القوم وبيانهم، واللهجات وجه مِن الوجوه ومصدر مِن المصادر التي تجتلب الغريب، فلا هذا ولا ذاك حَصَرَتهُ كتب الغربب المتأخرة لتستقيم تسميتها بكتب غريبٍ. إنَّ مِن الغريب ما أعيا الفصحاء الصرحاء مِن الصحابة وربما احتاج الى لطفٍ وتسديد في بيانه فجنَّله الباري تعالى مَن كثفِه وأوضحه فكانَ رسول الله مفتاحَ الغموض والمتكفّل لإزالة الابهام والاشكال وبيان ما أراده القرآن، والقرآن نفسه مصدر كثف، إذ إنَّ القرآن يُفَّر بعضه بعضاً ولكنَّ هذا يحتاج الى المتفطن الورع والمتأمّل الواعي فكان بعض الصحابة قد تصدَّى لمثل هذا كعلي بن ابي طالب (عليه السلام) الذي أجاب على كثير مّمِا أشكل وغَمَض على الصحابة انفهه وليس بغريب عليه، اذ انَّ علياً كان ربيب النبي (صلى الله عليه واله وسلم)وقد سمع من النبي (صلى الله عليه واله وسلم) ما لم يسمْعه غيرُه، وهو مصدر الهام ابن عباس الذي نُوةَ به كثيراً في هذا الموضع وهو الذي يقول: ((ما أخذتُ مِن تفسير القرآن فمن علي بن ابي طالب (عليه

$$
\text { السلام)()( نفسه ، } 59 \text {-62 ) ، ( القرطبي ، 2006، 46/1) • }
$$

أمّا كتب غريب الحديث فغلب عليها الاهتمام بالغريب حَقاً، وذلك لانَّ الحديث مَظِنةٌ الرواية، والرواة كُثرّ ، ويختلفون كثيراً أو قليلاً في النقل عن النبي (صلى الله عليه واله وسلم)، واكثرهم عرب اقحاح مطبوعون فيحصل الاختلاف في النقل بسبب سوء الفهم أو الحفظ أو بسبب اختلاف لهجاتهم التي تتحكم في تلقيهم وفي إيصالهم مَّمِا أدَّى إلى تَثَكَّل هذا الغريب الاًّ أنَّ في كتب الغريب أشياء ليس مِن الغريب في شيء، وأطلق عليها هذا الوصف توسّعاً ومجازاً ليس الآّ وقد أشار ابن الاثير الى ذلك تصريحاً، اذ إنَّ الالفاظ عنده عامَّ وخاص فالعام ((ما يشترك في معرفته جمهور اهل اللسان العربي مَّمِا يدور في الخطاب فهم في معرفته شرع سواء أو قريب من السواء، وامّا الخاص فهو ما ورد فيه مِن الالفاظ اللغويّة والكلمات الغريبة الحوشية التي لا يعرفُها الا من عُني 
بها وحافظ عليها واستخراجها مِن مظانها - وقليل ما هم - فكان الاهتمام بمعرفة هذا النوع الخاص مِن الالفاظ اهم مَّمِا سواه واولى بالبيان مّمِا عداه ومقدَّماً في الرتبة على غيره ومَنْدواً في التعريف بذكره، اذ الحاجة اليه ضرورية في البيان، لازمة في الايضاح والعزففان)(( ابن الاثير ، 2005،1 /4) ·

إنَّ هذا الذي ذكره ابن الاثير يُجمل ما نحن بصدده في محاولة اقصاء القسم الخاص بالألفاظ العامة التي يشترك فيها جمهور اهل اللسان مِن مَنََّّة الغريب، فهي وإنَّ ارتقت منَسَّة الفصاحة والبيان الاًّ انّها بعيدة كل البعد عن حقل الغريب ومفهومه. ولعل الامر يتضح بصورة أجلى فيما تُسى بكتب ((غريب اعراب القرآن)) التي اعتمد بعضها على بعض في تقديم المعلومة واعتمد مُؤلفُها في اعراب الآيات على ما جاء في كتب اعراب القرآن ومعانيه زاعمين أنَّها مِن الغريب مِن غير تسويخ أو تبرير لكثير مَّمِا توصلوا اليه، وهم كذلك اختلفوا في تحديد هذا النوع مِن غريب الاعراب فما عدَّه ابن قتيبة ومكي القيسي مِن الغريب المشكل في الاعراب لم يسلكه ابن الانباري والحيدرة اليمنى في هذا الباب، زيادة على اختلافهم في التوجيه الاعرابي للنصوص

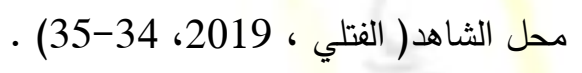
وممِا يدخل في باب اطلاق الغريب وابتذاله ووسْمِهِ بألفاظ أَحصيت منها: المعضل والعويص والمؤول والفريد والثاذ والمُحدَث والمولّد والجديد والمهمل والحوشي والوحشي والمبتذل. فأمّا الفاظ مثل المبهم والغامض والمشكل والبعيد والنادر فهي اوصاف للغريب - بلا شك عوقد يُكتْفى بها عن ذكر اسم الغريب ووصفه. وقد ذكرت في هذا المورد وصفهم بعض غريب الفاظ النبي بالوحشي ولا استحسنُه، لانَّ الوحشي مِن الكلام: ما نفر عن السمع، فأمّا ما ورد في كلام النبي (صلى الله عليه واله وسلم) منها فحسنٌ مستغرب يُحتاج الى فحص وتحرّ مِن العالم المُبرَّز . إلا أن هذه اللفظة ابتذلت بعد ذلك وانحرفت دلالتها بعد عصور الاحتجاج وقد حذَّر منها الادباء والكتاب، ذُكر أنّ إبراهيم بن المهدي أوصى كتابه بقوله: ((إيَّاك وتتبَّع حوشي الكلام طمعاً في نيل البلاغة، فإن ذلك هو العيَّ الأكبر وعليك بما سَهُل مع تجنّبك الفاظ السفل)(( السيوطي ، 1998، 186/1) . والذي يقف على النوع الثالث مِن كتاب المزهر للسيوطي في ((معرفة الحوشي والغرائب والثواذ والنوادر))، يجده يحُاول إحصاء الأسماء والصفات التي تتصل بلفظ الغريب ويسعى الى تقريب معانيها، فالحوشي والغرائب والثواذ والنوادر الفاظ متقاربة وكلها خلاف الفصيح، والثوارد منها وهي تدلَّ على ما سقط وشذّ عنده( نغسه ، 186/1-191) ، وهذا بلا شك - لا يوافق معنى ما 
قيدناه مِن الغريب القرآني والحديثي، فما نص عليه السيوطي اطلاق وابتذال في هذا الموضع، فهي وان التقت بالغريب واتصلت به مِن وجهٍ الآ أنّها تفارق الغريب في دلالتها التي نصَّ عليها السيوطي. وقد حدد ابن فارس وجهة نظره في الموضوع، اذ ذكر في كتابه ((الصاجي في فقه اللغة وسنن العرب في كلامها)) في باب: ((مراتب الكلام في وضوحه واشكاله)) أنَّ واضح الكلام الذي: ((يفهمه كلَّ سامع عرف ظاهر كلام العرب واما المشكل فالذي يأتيه الاشكال مِن غرابة لفظه، أو من ان تكون فيه إثارة الى خير لم يذكره قائله على جهته، أو ان يكون الكلام في شيء غير محدد أو يكون وجيزاً في نفسه غير مبسوط أو تكون الفاظه مشتركة))( (ابن فارس، 1963، 74) . فالغرابة عندِ ابن فارس وجه مِن وجوه الإشكال لا الاثكال نفسه وتداخل هذه المصطلحات هو الذي افضى الى هذا النوع من الابتذال والاطلاق الذي الفناه هنا. ولكن الذي يقوّى ما نقول في هذا الموضع أنَّ علماء اللغة والمعاني أفردوا لهذه الاصطلاحات ابواباً وحقولاً فللوحشي باب، وللشوارد والنوادر بابين آخرين وللشواذ آخر وكذا المشكل وللغريب باب، فلو كان الامر على الاتفاق لما أُفرد باب لكلّ منها، مَّمِا يعني اختصاص كُلّ مصطلح منها بخاصةٍ لا تجري في غيره. وَمَّمِا يجلب انتباه الباحث في هذا الموضع أنَّ حازماً القرطاجّني في كتابه ((منهاج البلغاء وسراج الادباء)) حين وقف على اقسام الكلمة وضع الغرابة قبالة الفصاحة وقرنها بالابتذال، ناسباً الغرابة والابتذال الى العامة، والقرطاجني - هنا - وظفَّ الغرابة في غير وجود الفصاحة، وهذا بخلاف ما وجدناه في العصور الأولى، اذ إنَّ المتكلمين حينذاك فصحاء ومطبوعون فيما يصدر عنهم، فضلاً على قرن القرطاجني الغرابة بالابتذال بمعنى شيوع اللفظ أو العبارة على ألسنة العوام مَّمِا يخرجُها مِن معايير الفصاحة عند القرطاجني. ويفهم من كلام حازم أنَّ هناك طبقات مِن الكلمات تتدرج على وفق المسمَّيات التي أطلقها فأعلاها ما وافق كلام العرب وكثر فيه ثم ما شاع عنِد الخواص دون عامتهم ثم ما شاع عندِ العامة، وقد نسب الغربب المبتذل الى العامة، وقد نفهم مِن كلامه تخصيص هذه الالفاظ بجمهور العوام، لان ((ما استعمله العرب وخاصة المحدثين فهذا حسن جداً، لأنه خلص مِن حوشية العرب وابتذال العامَّة)() القرطاجني، 1966، 385-386) . فالحوشي عند حازم غير مرغوب فيه والحوشي كما فهنا مِن كلام السيوطي في الكلام السابق لفظ مقارب للغريب وكلاهما بخلاف الفصيح. 


\section{مجلة لارك للفلسفة واللسدانيات والعدوم الاجتماعية المجلد (3) العدد (42) السدة (2021) بحوث اللغة الدعربية}

ويبدوا ان حازماً والسيوطي وجَّها الدصطلح على وفق هامشه الدلالي الذي يوافق كلام المولدين حينذاك، وإن حاولا وضع الحوشي الغريب في حقل المبهم تكلَفاً لا طبعاً، اذ إنَّ تكلف الغرابة والسعي في صناعتها مَّمِا ينافي طلب البلاغة ولإفصاح، وهذا بخلاف ما شاع في العصور السابقة في انتاج الغرابة طبعاً لا تكلفاً، ولا سيما في المتنين المقَّسين. فالغرابة التي نثأت في عصور المولَّين اتجهت نحو التغيير الدلالي الانحطاطي بفقدها صفة الفصاحة التي صبغت لغة المولدين في هذه العصور وجريانها على ألسنة طبقات مِن العوام لا سيما اهل الصنائع والمهن مَّمن اختصَّ بمستوى مِن الالفاظ لم يَيَّع عند غيره، مَّمِا خلقَ جمهوراً مِن الالفاظ الغريبة والمبتذلة عند طبقة مِن الناس دون أخرى فيشيع بين هؤلاء ويبتذل، ويعُمَى على الاخرين فيعُّ غريباً، والابتذال قد ينشأ مِن سخافة اللفظ وقبح دلالته وخصوصاً حين يشيع عند سفلة الناس أو جهلتهم فَيُعرف عِد هؤلاء وَيُجهل عند عامة الناس، ويستغربونه، فيجتمع في المسألة وجها الغرابة والابتذال( شاهر ،2012، 8-18). 
بعد دراسة مستفيضة ودراسة ليست بالقصيرة مع غريب اللغة في إصطلاحه ومفهومه وتأريخه في دراسات سابقة فقد كان يخالجني شعور بالتباين بين مستوى هذ الغريب وقيمته في عصور الإحتجاج عند المطبوعين وبين مستواه في العصور التي تلتها ، إذ كان له القِدح المعلى وشغل حيز الأصح والأفصح من متون اللغة ولا سيما القرآنية والحديثية وكلام العرب منظومه ومنثوره ثم أخذ بعد ذلك بالإنحدار والتهافت والإنفصام عن حقيقته المعهودة في العصور المتأخرة ، إذ تخلى عن قالب الفصاحة شيئا فثيئا وتبعه مفارقته عنصري الغموض والتوعر ( الصعوبة ) اللذين حكما وكانا مفصلاً في التمييز بين عِلْية اللغووين ومتعلميهم ، فجاءت الألفاظ أو النصوص التي وضعها المتأخرون في حقل الغربب أما سَوقية مبتذلة أو وحشية أو عامية نُزعت منها صفة

الفصاحة غالبا

ويمكن إجمال النتائج التي توصلنا إليها بالأتي :

1- لقد كانت الفصاحة والغموض قيدين متلازمين لغرائب اللغة في عصر المطبوعين ، إلا أن ذلك تهافت وإندثر أو كاد في العصور المتأخرة ، بل إبتذل وشاع إستعماله في الفصيح والغامض وغيرهما 2- لقد كانت الألفاظ والنصوص الغريبة تعتلي قمة الهرم اللغوي في الفصاحة واللطافة والرصانة ، ودليل ذلك ما صدر من الفاظ قرآنية وحديثية تدخل في هذا الباب ومما سُمع منه في كلام العرب منظومه ومنثوره وجرى على السنة الجهابذة والخواص

3- ومما يدخل في الغريب المُقيّد ما نُسب إلى لغات القرآن ولهجاته مما أُجري من وجوه المعرب ولهجات القرآن ، كاللغات التي احصاها ابن حسنون المقرئ فضلا على ما أفرزه العلماء من لطيف الألفاظ القرآنية والنبوية ورصينها ، مما تقرد به المتتان وما صدر من الفحول منظوما أو منثورا وما هُجر وكثفه خواص العلماء وجهابذتهم • ومن الغريب المبتذل ما شاع وذاع بعد ذلك عند العرب في البيئات العربية المختلفة من الفاظ سَوقية ومولدة ووحشية لا ترقى إلى مستوى الفصاحة في أي حال ، ومنه الألفاظ أو النصوص التي حشاها بعض العلماء من المفرين وأهل المعاني في هذا الباب وهي ليست منه ، وأعني الألفاظ الواضحة الدلالة والبينة المعنى ، ويمكن الوقوف على ذلك فيما يسمى بكتب غريب القرآن والحديث وما نُسب إلى وجوه الإعراب من غرابة لا يمكن عدها منه لجريها على المعهود من بيانات النحويين في هذا الباب ، فهذا - بلا شك - مما سميناه بالغريب المبتذل ، ومنه ما شاع إستعماله وطغت عليه صفة العمومية في المعنى ، فققد الطرافة والخصوصية التي عهدناها في الغريب الحقيقي الذي شاع في متون العربية المعتبرة 
ثبت المصادر والمراجع

- الترآن الكريم

1- ابن الاثير ، مجد الدين (2005) ، النهاية في غريب الحديث والاثر ، تح : طاهر الزاوي ومحمود الطناحي ، ط1 ، قم انتشارات دار التقسير

2- ابن التركماني ، علي ابن عثمان (2002) ، بهجتة الاريب في بيان مافي كتاب الله العزيز من الغريب ، تح : مرزوق علي ابراهيم ، الهيئة المصرية العامة للكتاب

3- ابن جني ، ابو الفتح (1999) ، الخصائص ، تح : محمد علي النجار ، ط1 ، الهيئة المصرية العامة للكتاب 4- ابن الجوزي ، ابو الفرج ، (1985) ، تح : د. عبدالمعطي امين قلعجي ، بيروت ، دار الكتب العلمية 5- ابن حسنون ، المقرئ ، (1972) ، كتاب اللغات في القرآن ، تح: د.صلاح الدين المنجد ، ط2 ، بيروت ، مطبوعة الرسالة 6- - ابن دريد ، ابو بكر ، (1932) ، ط1 ، دار صادر 7- ابن سيده ، (2000) ، المحكم والمحيط الاعظم ، معهز المخطوطات العربية

8- ابن فارس ، احمد ، (1993) ، معجم مقاييس اللغة ، تح : د. شهاب الدين ابي عمر ، بيروت ، دار الفكر 9- ابن فارس ، احمد ، (1994) ، كتاب مجمل اللغة ، تح : د. شهاب الدين ابي عمر ، بيروت ، دار الفكر 10- ابن فارس ، احمد ، (1963) ، الصاحبي في فقه اللغة وسنن العرب في كلامها ، تح: مصطفى الثوبني ، بيروت ، مؤسسة بدران 11- ابن منظور ، ابوالفضل ، (2010) ، لسان العرب ، بيروت ، دار صادر 12- البيرجندي ، حسين الحسيني ، (2000) ، غريب الحديث في رحاب الانوار ، تح: مركز بحوث دار الحديث ، ط1، طهران ، مؤسسة الطباعة والنشر 13- التهانوي ، محمد بن علي ، (1996) ، تح: علي دحروج ، ط1، منشورات مكتبة لبنان 14- الجواري ، د. عبدالستار ، (1974) ، نحو القرآن ،بغداد ، مطبعة المجمع العلمي العراقي 15- الجوهري ، ابو نصر ، (1999) ، تح: د. اميل يعقوب و د. محمد الطريفي ، ط1 ، دار بيروت ، دار الكتب العلمية 
16- الخطابي ، ابو سليمان ، (1982) ، تح: د. عبدالكريم العزباوي ، دمشق، دار الفكر

17- الدينوري ، ابن قتيبة ، (2007) ، تأويل مشكل القرآن ، ضبط : ابراهيم شمس الدين ، ط2 ، بيروت ، دار الكتب

العلمية

18- الدينوري ، ابن قتيبة ، ( 2007) ، تقسير غريب القرآن ، تح: السيد احمد صقر ، بيروت ، دار الكتب العلمية

19- الدينوري ، ابن قتيبة ، (1977) ، تح: د. عبدالله الجبوري ، ط1، بغداد ، مطبعة العاني

20- الازهري ، ابو منصور ، (2004) ، تح: احمد عبدالرحمن مخيمر ، ط1، بيروت ، دار الكتب العلمية

21- الزجاجي ، ابو القاسم ، (1973) ، الايضاح في علل النحو ، تح: مازن مبارك ، بيروت ، دار النفائس

22- الزركثي ، بدر الدين ، (1990) ، بيروت ، دار المعرفة

23- الزمشري ، جار الله ، (2007) ، تح: محمد باسل عيون السود ، بيروت دار الكتب العلمية

24- السالم ، د. صباح ، (2002) ، بغداد ، دار الكتب والوثائق

25- السامرائي ، د. ابراهيم ، (1968) ، سؤالات نافع بن الازرق الى عبدالله بن عباس ، بغداد ، مطبعة المعارف

26- السيوطي ، جلال الدين ، (1998) ، المزهر في علوم اللغة وانواعها ، ضبط : فؤاد علي منصور ، ط1، بيروت ،

$$
\text { دار الكتب العلمي }
$$

27- السيوطي ، جلال الدين ، (2011) ، ضبط: محمد سالم هاشم ، مكتبة فخر الدين

28- الثهيد زيد ، (1957) ، كتاب غريب القرآن ، تح: محمد جواد الحسيني ، ط2، قم ، طبع مكتب الاعلام الاسلامي 29- الصغاني ، الحسن ابن محمد ، (1970) ، التكملة والذيل ، والصلة لكتاب تاج اللغة وصحاح العربية ، تح: عبدالعليم الطحاوي ، القاهرة ، مطبعة دار الكتب

30- الطريحي ، فخر الدين ، (1985) ، منشورات دار مكتبة الهلال 31- عبدالقاهر ، الجرجاني ، (2004) ، تح: محمود محمد شاكر ، القاهرة ، مكتبة الخانجي 32 - عراب ، مهدي اسعد،(2003) ، ظاهرة اللبس في العربية ، جدل التواصل والتفاصل ، ط1، عمان ، دار وائل للنشر والتوزيع

33- الفراهيدي ، الخليل ، (1982) ، كتاب العين ، تح: د. مهدي المخزومي و د. ابراهيم السامرائي ، عمان ، دار الرشيد 
34- القرطاجني ، ابو الحسن ، (1966) ، منهاج البلغاء وسراج الادباء ، تح: محمد الحبيب بن الخوجة ، تونس ، دار

$$
\text { الكتب الثرقية }
$$

35- القرطبي ، ابو عبدالله ، (2006) ، الجامع لاحكام القرآن والمبين لما تضمنه من السنة وآي الفرقان ، تح: عبدالله بن

عبدالمحسن التركي ، مؤسسة الرسالة

36- كبار اللغويين ، المعجم الوسيط ، (1979) ، اسطنبول ، دار الدعوة

37- لاروس ، المعجم العربي الاساسي ، (1988) ، جملة من كبار اللغويين ، المنظمة العربية للتربية والثقافة والعلوم 38 - المجلسي ، محمد باقر ، (1986) ، بحار الانوار الجامعة لدرر اخبار الائمة الاطهار ، ط2، بيروت ، مؤسسة الوفاء 39- الجواري ، د. احمد ، (1974) ، بغداد ، مطبعة المجمع العلمي العراقي 40- الهروي ، قاسم ابن سلام ، (2003) ، ط2، بيروت ، دار الكتب العلمية

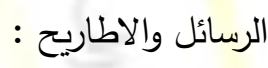

1- الفتلي ، مجيد حميد ، (2019) ، الحذف والتقدير في كتاب ( البيان في غريب اعراب القرآن ) لابي البركات ابن الانباري ، اطروحة دكتواره ، العراق ، جامعة القادسية ، كلية الاداب

2- شاهر ، كاظم فضيل ، (2008) ، اللغات في كتب غريب الحديث ، اطروحة دكتواره ، العراق ، كلية التربية ، جامعة بابل المجلات العلمية المحكمة 1- شاهر ، د.كاظم فضيل ، (2012) ، مجلة العلوم الانسانية ، العدد الثاني ، العراق ، جامعة بابل 
List the sources and references

- Holy Quran

1- Ibn Al-Atheer, Majd Al-Din (2005), The End in Gharib Hadith and Athar, edited by: Taher Al-Zawi and Mahmoud Al-Tanahi, 1st Edition, Qom publications, Dar Al-Tafsir

2- Ibn Al-Turkmani, Ali Ibn Othman (2002), Bahjat Al-Areeb in a statement about what is in the Holy Book of God from the stranger, edited by: Marzouk Ali Ibrahim, Egyptian General Book Authority

3- Ibn Jani, Abu al-Fath (1999), al-Khasifat, edited by: Muhammad Ali al-Najjar, 1st edition, the Egyptian General Book Organization.

4- Ibn Al-Jawzi, Abu Al-Faraj, (1985), edited by: Dr. Abdel-Moati Amin Kalaji, Beirut, House of Scientific Books

5- Ibn Hasanun, Al-Muqari, (1972), the Book of Languages in the Qur'an, edited by: Dr. Salah Al-Din Al-Munajjid, 2nd Edition, Beirut, Al-Risala Publication

6- Ibn Duraid, Abu Bakr, (1932), edition 1, Dar Sader

7- Ibn Sayyida, (2000), the arbitrator and the greater ocean, the Institute of Arabic Manuscripts 8- Ibn Faris, Ahmed, (1993), a dictionary of language standards, edited by: Dr. Shihab El-Din Abi Omar, Beirut, Dar Al-Fikr

9- Ibn Faris, Ahmed, (1994), Majmal Al-Lughah Book, edited by: Dr. Shihab El-Din Abi Omar, Beirut, Dar Al-Fikr

10- Ibn Faris, Ahmad, (1963), Al-Sahbi in Fiqh of Language and Sunan Al-Arab in Her Words, edited by: Mustafa Al-Shobni, Beirut, Badran Foundation

11- Ibn Manzur, Abul Fadl, (2010), Lisan Al Arab, Beirut, Dar Sader 
12- Al-Berjandi, Hussein Al-Husseini, (2000), Gharib Hadith in Rehab Al-Anwar, edited by: Dar Al-Hadith Research Center, 1st floor, Tehran, Printing and Publishing Corporation

13- Al-Thanawy, Muhammad bin Ali, (1996), edited by: Ali Dahrouj, 1st Edition, Library of Lebanon Publications

14- Al-Jawari, Dr. Abdul Sattar, (1974), Towards the Qur'an, Baghdad, the Iraqi Scientific Academy Press

15- El-Gohary, Abu Nasr, (1999), edited by: Dr. Emile Yacoub and Dr. Muhammad Al-Tarifi, 1st floor, Beirut House, Scientific Books House

16- Al-Khattabi, Abu Suleiman, (1982), edited by: Dr. Abdul Karim Al-Azbawi, Damascus, Dar Al-Fikr

16- Al-Khattabi, Abu Suleiman, (1982), edited by: Dr. Abdul Karim Al-Azbawi, Damascus, Dar Al-Fikr

17- Al-Dinouri, Ibn Qutaybah, (2007), Interpretation of the problem of the Qur'an, tuned by: Ibrahim Shams al-Din, 2nd Edition, Beirut, Dar al-Kutub al-IImiyya

18- Al-Dinori, Ibn Qutayba, (2007), the strange interpretation of the Qur'an, edited by: Mr. Ahmed Saqr, Beirut, Dar Al-Kutub Al-IImia

19- Al-Dinori, Ibn Qutayba, (1977), edited by: Dr. Abdullah Al-Jubouri, 1st floor, Baghdad, AlAni Press

20- Al-Azhari, Abu Mansour, (2004), edited by: Ahmed Abdel Rahman Mukhaimer, 1st floor, Beirut, Dar Al-Kutub Al-IImia.

21- Al-Zajji, Abu Al-Qasim, (1973), The Clarification of the Reasons for Grammar, edited by: Mazen Mubarak, Beirut, Dar Al-Nafais. 
22- Al-Zarkashi, Badr Al-Din, (1990), Beirut, Dar Al-Marifa

23- Al-Zamakhshari, Jarallah, (2007)

24- Al-Salem, Dr. Sabah, (2002), Baghdad, House of Books and Documents

25- Al-Samarrai, d. Ibrahim, (1968), Questions from Nafi' bin Al-Azraq to Abdullah bin Abbas, Baghdad, Al-Maaref Press.

26- Al-Suyuti, Jalal Al-Din, (1998), Al-Mizhar in the Sciences of Language and its Kinds, Edited by: Fouad Ali Mansour, 1st Edition, Beirut, Dar Al-Kutub Al-Alami

27- Al-Suyuti, Jalal Al-Din, (2011), Editing: Muhammad Salem Hashem, Fakhr Al-Din Library

28- Martyr Zaid, (1957), The Strange Qur'an Book, edited by: Muhammad Jawad Al-Husseini, 2nd Edition, Qom, printed by the Islamic Information Office

29- Al-Saghani, Al-Hasan Ibn Muhammad, (1970), the supplement and the tail, and the link to the book "The Taj Al-Lughah wa Sahih Al-Arabiya" book, edited by: Abdel Alim Al-Tahawi, Cairo, Dar Al-Kutub Press

30- Al-Taraihi, Fakhr El-Din, (1985), Publications of the Crescent Library House 31- Abdel-Qaher, Al-Jerjani, (2004), edited by: Mahmoud Muhammad Shaker, Cairo, Al-Khanji Library

32- Arrab, Mahdi Asaad, (2003), the phenomenon of confusion in Arabic, the controversy of communication and detail, 1st floor, Amman, Dar Wael for Publishing and Distribution.

33- Al-Farahidi, Al-Khalil, (1982), Al-Ain book, edited by: Dr. Mehdi Makhzoumi and d. Ibrahim Al-Samarrai, Amman, Dar Al-Rasheed

34- Carthaginian, Abu Al-Hassan, (1966), Minhaj Al-Balagha and Siraj Al-Adabaa, translated by: Muhammad Al-Habib Ibn Al-Khawja, Tunisia, Dar Al-Kutub Al-Sharqiya 
35- Al-Qurtubi, Abu Abdullah, (2006), The Collector of the Provisions of the Qur'an and the Explanation of what it contains from the Sunnah and Ay Al-Furqan.

36- Senior Linguists, The Intermediate Dictionary, (1979), Istanbul, Dar Al-Da`wah

37- Larousse, The Basic Arabic Dictionary, (1988), a group of eminent linguists, Arab Organization for Education, Culture and Science

38- Al-Majlisi, Muhammad Baqir, (1986), Bihar Al-Anwar Al-Jami'ah, Al-Durar News of the Pure Imams, 2nd Edition, Beirut, Al-Wafa Foundation

38- Al-Majlisi, Muhammad Baqir, (1986), Bihar Al-Anwar Al-Jami'ah, Al-Durar News of the Pure Imams, 2nd Edition, Beirut, Al-Wafa Foundation

39- Al-Maawary, Dr. Ahmed, (1974), Baghdad, the Iraqi Scientific Academy Press

40- Al-Harawi, Qassem Ibn Salam, (2003), 2nd floor, Beirut, Dar Al-Kutub Al-Ilmia

Messages and theses:

1- Al-Fatli, Majid Hamid, (2019), omission and appreciation in the book (Al-Bayan fi Gharib A'rab Al-Quran) by Abu Al-Barakat Ibn Al-Anbari, his doctoral thesis, Iraq, Al-Qadisiyah University, College of Arts

2- Shaher, Kazem Fadeel, (2008), Languages in Gharib Hadith books, his doctoral thesis, Iraq, College of Education, University of Babylon

Refereed scientific journals

1- Shaher, Dr. Kazem Fadeel, (2012), Journal of Human Sciences, No. 2, Iraq, University of Babylon. 